\title{
Ilmastodiskurssi Venäjän arktisella alueella
}

Artikkelissa tarkastellaan, voisivatko vuonna 2016 Jamalin niemimaalla luoteisSiperiassa ilmenneet pernaruttotapaukset haastaa Venäjällä vallitsevaa diskurssia, jossa mahdollisesti pernaruton ilmenemisen taustalla oleva ilmastonmuutoksen ongelma sivuutetaan. Artikkelissa pohditaan, miten mahdollinen haaste vallitsevalle diskurssille ilmenisi. Tutkimus perustuu rajattuun otokseen kansallisen ja paikallisen tason mediasisältöjä, joissa pernarutto liitettiin ilmastonmuutokseen. Analyysi hyödyntää poststrukturalistisen diskurssiteorian oletuksia sekä dislokaation ja diskursiivisen logiikan käsitteitä ja kohdistuu talouskehityksen ja ympäristön muutoksen suhteeseen alueella, joka on yhtä aikaa keskeinen Venäjän fossiilitaloudelle sekä haavoittuva ilmastonmuutoksen vaikutuksille. Tulokset osoittavat esteitä ja mahdollisuuksia ilmasto-oikeudenmukaisuuden toteutumiselle tässä viitekehyksessä.

Dmitry Yagodin

Vuonna 2016 otsikot venäläisissä tiedotusvälineissä varoittivat: "Pohjoinen on tulessa" (Borisov 2016), "Vaikea kesä porojen valtakunnassa" (Egorova 2016), "Greenpeace syyttää ilmastonmuutosta pernaruton puhkeamisesta Jamalilla" (Kommersant 2016), "Ensimmäiset pernaruttotapaukset 75 vuoteen kukistavat Jamalin" (Avakov 2016). Eräässä otsikossa lainattiin paikallisen asukkaan salaliittoepäilyä: "Meille kerrottiin, että ulkomaalaiset levittävät bakteeria lentokoneesta" (Britskaia 2016). Alueellisen ja paikallisen lehdistön suhtautuminen oli käytännöllisempää: "Jamalilla ei ole epidemiaa, karanteeni on paikallinen" (Rybiakova 2016). "Tundra vastustaa taloutta: Ekologinen katastrofi on väistämätön ellei porojen määrää Jamalilla rajoiteta" (Melnikova 2016). Alueellisessa mediassa ilmastonmuutosta ei mainittu lainkaan ja helteisiin viitattiin vain satunnaisesti lukuun ottamatta kirjoituksia muutamaa kuukautta myöhemmin järjestetystä symposiumista, joka käsitteli tartuntatautien torjuntaa 
ilmastonmuutoksen yhteydessä. Tällöinkin paikalliset journalistit korostivat ilmastonmuutoksen sijaan sitä, miten kansainväliset asiantuntijat kuvasivat "Jamalin metodia pernaruton torjunnassa" (Gancherko 2016) ainutlaatuiseksi.

Vaikka nämä otsikot eivät edusta kaikkia kansallisia ja alueellisia aineistoja, olen tarkoituksella valinnut ne, joissa eroavaisuudet näkyvät selvimmin. Niissä käytetyistä sanoista "pernarutto" keräsi eniten mediahuomiota. Kyseessä on harvinainen tartuntatauti, jonka aiheuttaa Bacillus anthracis - erittäin vaarallinen, elinvoimainen ja tarttuva bakteeri. Se sairastuttaa yleensä eläimiä, joiden kautta tauti voi siirtyä ihmisiin. Sitä voidaan myös käyttää biologisena aseena, ja se edellyttää sotilaallisen tason dekontaminaatiokeinoja. Tämä tutkimus keskittyy analysoimaan suhteellisen pientä joukkoa väittämiä, joissa - toisin kuin valtaosassa Venäjän mediaa - yhdistettiin pernarutto mediakentässä muutenkin marginaalisessa asemassa olevaan ilmastonmuutokseen (Yagodin 2017; Poberezhskaya 2015). Tutkimuksen empiirinen aineisto koostuu alueellisen ja paikallisen median uutisista, jotka ovat ilmestyneet kahden kuukauden sisällä siitä, kun ensimmäisistä pernaruttotapauksista raportoitiin heinäkuun 2016 lopussa. Keskeinen huomio on kohdistunut lehtiartikkeleihin, joissa on käsitelty pernaruttoa, mutta viitattu myös ilmastonmuutokseen. Venäjän vähäisessä ilmastonmuutokseen keskittyneessä uutisoinnissa hyödynnetään usein asiantuntijalausuntoja, jotka ovat tärkeitä tietolähteitä mutta samalla niitä käytetään tukemaan hallituksen politiikkaa, joka vaihtelee kansainvälisen agendan ja kansallisten taloudellisten etujen mukaan.

Tutkimuksen tarkoituksena on tarkastella, miten Venäjän tapauksessa vakiintuneen ilmastopolitiikka-agendan puuttuminen ja yleisessä keskustelussa vallitseva tietämättömyys ilmastonmuutoksesta vaikuttavat vaihtoehtoisten diskurssien muodostumisen. Analyysissa hyödynnetään erityisesti pluralistisen ilmasto-oikeudenmukaisuuden (Schlosberg 2009) näkökulmaa. Tässä yhteydessä pluralismi tarkoittaa, että ilmasto-oikeudenmukaisuus ei ole universaalia, muttei myöskään rajoitu resurssien jaon, tunnistamisen, osallisuuden ja toimintamahdollisuuksien kaltaisiin tavanomaisiin määrittelyihin. Pluralistisen lähestymistavan argumentit perustuvat määrättyihin yhteiskunnallisiin ja luonnollisiin konteksteihin. Kansainväliset ilmasto-oikeudenmukaisuusliikkeet pyrkivät muun muassa edistämään investointien irrottamista fossiilienergiaan perustuvasta teollisuudesta. Tämä tavoite ei kuitenkaan ole realistinen Venäjän kaltaisessa hiilivetykulttuuriin perustuvassa energiantuottajamaassa, jossa poliittiset ja tiedotusvälineiden vapaudet eivät toteudu. (Tynkkynen 2019.) Vallitsevan diskurssin haastaja löytyykin helpommin pluralistisesta ilmasto-oikeudenmukaisuudesta, joka näkee kysymyksen sosioekologisena ongelmana.

Millaiset mahdollisuudet ilmastodiskurssilla on puuttua vallitseviin, ilmastonmuutosta huomioimattomiin diskursseihin ja haastaa niitä paikallisen ja kansallisen tason mediajulkisuuden kautta? Löytääkseen vastauksen tähän kysymykseen, artikkeli seuraa poststrukturalistisen diskurssiteorian perusoletuksia (Glynos \& Howarth 2007; Laclau 1990). Aluksi artikkeli tarjoaa tapaustutkimuksen kontekstuaalisen taustan. Tämän jälkeen se määrittelee pernaruttotapauksen dislokatoriseksi hetkeksi eli dominoivan diskurssin kriisiksi (Stavrakakis 2000; Laclau 1990). Seuraavaksi esitellään empiirinen aineisto ja liitetään se diskurssianalyysiin Greenpeacen mediakampanjasta. Analyysi etenee ongelmalähtöisen metodologian mukaisesti keskittyen niihin diskursiivisiin logiikkoihin (Glynos \& Howarth 2007; Remling 2018), jotka rajoittavat ilmasto-oikeudenmukaisuuden diskurssia Venäjän mediassa. 


\section{Sosio-ekologinen ja poliittinen konteksti}

Edellä kuvatut otsikot viittaavat tiettyyn, rajattuun paikkaan Pohjois-Venäjällä - toisin sanoen Jamalin niemimaahan, joka sijaitsee yhdessä Venäjän kaukaisimmista ja harvimmin asutuista arktisista alueista, Jamalin Nenetsiassa. Pohjoisen Jäämeren rannalla sijaitsevasta Jamalin Nenetsiasta noin puolet on tundraa ja puolet taigaa. Pohjoisessa olevat avoimet tundraalueet, mukaan lukien koko Jamalin niemimaa, ovat elintärkeitä poronhoidosta elantonsa saavalle paimentolaiskulttuurille. Heidän elinkeinonsa ei sovi eteläisemmälle metsäalueelle, missä painentolaisten pitäisi asettua aloilleen, vaihtaa kotieläintalouteen ja tulla siten entistä riippuvaisemmiksi hallituksen taloudellisesta kontrollista. Vaikka alueen nimi korostaa alkuperäiskansaa, sen noin puolesta miljoonasta asukkaasta vain noin $30000(6 \%)$ on nenetsejä. Heidän osuutensa on suurin Jamalin niemimaalla, jossa nenetsejä onkin enemmistö asukkaista. Koska alueella on myös paljon öljyä ja kaasua, sen talous on viime vuosina kasvanut nopeasti. Tämä on vaatinut kompromisseja suuryhtiöiden, paikallisen väestön ja alkuperäiskansan nenetsien välillä. Alueesta on tullut yksi Venäjän johtavia talouskeskuksia ja sijoituskohteita. Fossiiliteollisuuden ja jatkuvasti kasvavan poronhoidon yhteiselo on luonut jännitteitä, vaikka onnistuneitakin esimerkkejä yhteisistä eduista on. Yritysmaailman PR-työn, hallituksen mainoskampanjoiden ja valtio-omisteisen median tehtäväksi on jäänyt siloitella alkuperäiskansan, yritysjohtajien, työntekijöiden ja muiden kansanosien sekä ulkomaisten sijoittajien välisiä suhteita.

Heinäkuu 2016 oli poikkeuksellisen kuuma Jamalin niemimaalla. Alueella ilmeni maapallon lämpötilan suurin poikkeama monivuotisesta keskiarvosta, ja 34 Celsiukseen kohonnut lämpö kärvensi tundran alaista ikiroutaa ja alueen kylmässä viihtyviä eläin- ja kasvilajeja. Tieteilijöiden mukaan kuumuus sulatti jäätynyttä maata, jonka uumenissa pernaruttoitiöt olivat olleet vankina vuosikymmeniä (esim. Timofeev et al. 2019). Kuolettava bakteeri tarttui maata kuopiviin poroihin, tappoi niitä yli 2000 ja tarttui myös poroja paimentaviin nenetseihin. Yksi 12-vuotias poika menehtyi sairaalassa. Alueen edellinen pernaruttoesiintymä oli ollut vuonna 1941, ja paikallisviranomaiset olivat alkaneet ajatella, ettei taudista enää olisi vaaraa. Kallis pakollisten rokotusten ohjelma oli lopetettu vuonna 2007, mikä helpotti heti taloudellista taakkaa ja hallituksen kontrollia paimentolaiskotitalouksista (Laishev \& Zabrodin 2012). Rokotusjärjestelmä palautettiin välittömästi uuden pernaruttoesiintymän jälkeen, mutta monet paimentolaisista suhtautuivat siihen vastahakoisesti ja yrittivät piilottaa porojaan. Pernaruton hallintakyky nousi tärkeään rooliin kaikkien alueen toimijoiden näkökulmasta niin paikallisen kuin ulkoisen julkisuuden kannalta.

Pernaruton puhkeaminen nivoutuu osaksi monimutkaista vyyhteä, johon liittyvät muun muassa taloudellinen kehitys, alkuperäiskansojen oikeudet ja ympäristön muutos Venäjän arktisella alueella. Tämän vuosisadan alusta asti Venäjän johtavat fossiilienergiayhtiöt ovat, ulkomaalaisten sijoittajien ja teknologioiden tukemina, päässeet hyödyntämään maailman suurimpia maakaasuvarantoja Jamalilla ja sen lähialueilla. Jamalilla asuu tuhansia nenetsejä, jotka ovat ainoa paimentolaiselämän säilyttänyt ja jatkuvasti karjamääräänsä kasvattanut Venäjällä asuva alkuperäiskansa (Klokov 2013). Joka vuosi nenetsiperheet ja noin 300000 poroa kulkevan läpi niemimaan kilpaillen laidunalueista, joiden määrä on vähentynyt ja laatu huonontunut sekä liiallisen karjamäärän että teollisuuden leviämisen vuoksi. Etsiessään syitä pernaruton puhkeamiseen, paikallinen sanomalehti Kranyi Sever keräsi asiantuntijalausuntoja:

Tieteilijöiden mukaan tauti oli levännyt 75 vuotta, mutta kuumuus ja (...) lisääntynyt poronhoito olivat herättäneet sen. Jamal on valtava, mutta laidunalueen määrästä tulee silti 
tiukkaa, toteavat arktisen alueen parissa vuosikausia työskennelleet tieteilijät. (Kolosov 2016.)

Johtopäätös vahvistaa tieteen auktoriteettia vetoamalla haastateltujen asiantuntijoiden paikalliseen ja pitkällä aikavälillä todennettuun tietoon. Samalla uutinen kiistää, että alueen intensiivinen teollinen hyödyntäminen voisi olla syynä taudin puhkeamiseen.

Ilmastonmuutos aiheuttaa Jamalilla entistä enemmän ja pahempia äärisääilmiöitä, mikä on jo johtanut massiivisiin karjamenetyksiin viime vuosien aikana. Nenetsien kyky sopeutua ympäristön muutoksiin on kuitenkin niin hyvä, että ilmastonmuutos vaivaa heitä vähemmän kuin alueelle tullut teollisuus, joka valtaa heidän maitaan ja rajoittaat nenetsien sopeutumismahdollisuuksia. (Forbes \& Stammler 2009; Degteva \& Nellemann 2013; Golovnev 2017). Vastareaktiona vuoden 2016 tautitapauksiin viranomaiset väittivät, että paimentolaiset olivat ylittäneet rajat kielletylle alueelle, missä sijaitsi vanhoja hautuumaita, sillä heidän perinteiset reittinsä eivät enää tarjonneet riittävästi ravintoa liian suureksi kasvaneelle karjamäärälle. Virallinen lausunto ei maininnut, että tilaa rajoitti myös kaasu- ja öljy-yhtiöiden kasvava määrä. Koska hallitus kotrolloi alueellista mediaa, paikallista diskurssia hallitsi tämä virallinen linja. Vaihtoehtoisia tulkintoja levisi sosiaalisessa mediassa ja muutamassa, näkyvyydeltään vähäisessä kansallisessa viestimessä. Yllättävää on myös se, ettei edes vaihtoehtoisissa diskursseissa mainita ilmastonmuutosta mahdollisena syynä, vaikka kansallinen meteorologian laitos ja Venäjän Greenpeacen julkisuuskampanja ovat asian nostaneet esiin.

Pernaruttotapaus tarjoaa hyödyllisiä huomioita teoreettiseen ilmastonmuutosdiskurssiin. Tutkimusten mukaan ilmastonmuutos ja siihen liittyvä arktisen ikiroudan sulaminen lisäävät tarttuvien tautien aktivoitumisen ja leviämisen riskiä (Walsh et al. 2018; Revich \& Podolnaya 2011). Ilmasto muuttuu arktisella alueella vielä maailman keskiarvoa nopeammin, mutta vähäisen väestöntiheyden vuoksi käsitys paikallisen sopeutumisen kiireellisyydestä ja tärkeydestä on kehittynyt hitaasti. Toisaalta arktisesta alueesta on tullut tärkeä maantieteellinen ja geopoliittinen kohde, joka on kerännyt globaalisti huomiota alkuperäiskansojen oikeuksia, luonnonvaroja ja kansainvälistä yhteistyötä koskeviin kysymyksiin (Gritsenko \& Tynkkynen 2016). Pernaruttotapaus on merkittävä myös käytännöllisistä syistä. Taudin puhkeamisen jälkeen Jamalin viranomaiset määräsivät karanteenitoimenpiteitä pinta-alaltaan valtavalle alueelle ja puolustusvoimien biologiseen sodankäyntiin erikoistuneet osastot osallistuivat puhdistusoperaatioihin elokuun 2016 aikana. Tapauksella oli kaikki edellytykset vetää julkisen keskustelun huomiota ilmastonmuutoksen ongelmaan arktisella alueella, sillä tiedotusvälineet yleensäkin käsittelevät ilmastokysymyksiä eniten äärisääilmiöiden ja hätätiloihin liittyvän pelon ja alarmismin yhteydessä (Boykoff 2008).

\section{Poststrukturalistinen diskurssiteoria ja ympäristöasiat}

Pitkään unohduksissa ollut sairaus uhkasi yllättäen Jamalin mainetta - jota tosin yhteiskuntatieteilijät ovat muutenkin kyseenalaistaneet - yhtenä Venäjän johtavista talousalueista, missä oli samalla onnistuneesti tasapainoiltu suuryhtiöiden ja alkuperäisyhteisöjen intressien välillä. Poststrukturalistisen diskurssiteorian (Laclau 1990) mukaan tällaisissa olosuhteissa syntyy usein uusia diskursseja, kun aikaisemmat sosiaaliset rakennelmat häiriintyvät. Glynos ja Howarth määrittelevät häiriön tai dislokaation (dislocation) hetkenä, jolloin "subjekti häiriintyy jostakin sellaisesta kokemuksesta, jota ei voi symbolisoida millään aikaisemmalla diskursiivisen edustuksellisuuden tavalla" $(2007,14)$. Dislokaatio avaa hegemonisia diskursseja vaihtoehtoisille, vastahegemonisille interventioille ja mahdollistaa siten muutoksen. 
Stavrakaksi (2000) tarkentaa, että vihreät liikkeet olivat täysin uuden ideologian tuote, joka syntyi vaiheittain kaksinkertaisesta dislokaatiosta ja joka sai alkunsa 1960-luvulla. Ensimmäinen näista dislokaatioista koski sosialistisen ideologian heikentymistä ja lopulta epäonnistumista. Vasemmistoliikkeen oli pakko etsiä uusia poliittisia kiintopisteitä ja uusvasemmisto radikaalisti laajensikin perinteistä työväenliikettä kattamaan sosiaalisen oikeudenmukaisuuden spektrumia ottaen mukaan myös ympäristökysymyksiä. Toinen oleellinen dislokaatio vihreän liikkeen synnyssä koskeekin muutoksia tavassa, josta luonnosta voitiin puhua pahenevan ekologisen kriisin valossa. Tämä dislokaatio näkyi ehkä selvimmin siinä, miten Tšernobylin ydinvoimakatastrofi loi aivan uusia käsityksiä ihmisen vaikutuksesta luontoon. Kun akuutit identifioitumisen ja representaatioiden kriisit aiheuttavat häiriöitä hegemonisiin diskursseihin, ne saattavat muodostaa uusia poliittisia identiteettejä, joihin vaikuttavat lisäksi ulkoiset kontekstit ja diskursiiviset resurssit.

Jamalin pernaruttotapauksen voi käsitteellistää potentiaalisena dislokaationa, joka tarjosi uusia luontoon ja ilmastoon liittyviä ilmaisukeinoja alkuperäiskansa nenetseille. Mikäli tämä alkuperäinen dislokaatio todella tapahtui, vaatii vastahegemoninen liike Stavrakisin (2000) mukaan myös toisen dislokaation. Nenetsien pitäisi esimerkiksi asettua antagonistiseen asemaan suhteissaan tahoihin, jotka ovat vastuussa paitsi suorasta ympäristön tuhoamisesta (jota öljy- ja kaasuyhtiöt yleensä kompensoivat kelvollisesti hyväntekeväisyydellä ja muulla tukitoiminnalla), mutta myös fossiilienergiantuotannon vähemmän ilmeisistä vaikutuksista globaaliin ja paikalliseen ympäristöön.

Talouskasvun ja ympäristönsuojelun välistä jännitettä tarkastellaan usein poliittisen talouden näkökulmasta. Esimerkiksi Australian kaasun tuotantoon keskittyvä tutkimus osoittaa, että fossiilisten polttoaineiden suhteen rikkailla alueilla taloudellisen kehityksen diskurssi tukeutuu usein neoliberaaleihin käsitteisiin, joissa paikallishallinnon ja fossiilienergiayhtiöiden diskursiiviset yhteenliittymät normalisoivat luonnonvarojen hyödyntämisen ja ulkomaiset investoinnit (Mercer et al. 2014). Kyseisen diskurssin toisintaminen ja siihen fiksoituminen onnistuu käyttämällä kasvun ja vaurauden hegemonisia ilmaisuja, jotka yhdistävät liikeelämän ja julkisen hallinnon pyrkimyksiä. Neoliberaalia ajattelua vastustavat diskursiiviset elementit, joita esittävät esimerkiksi vaihtoehtoisia kehitysskenaarioita kannattavat ympäristöaktivistit, jätetään dominoivan diskurssin ulkopuolelle. Tämä kaventaa tarjolla olevia vastarinnan käytäntöjä ja vastahegemonisten liittoutumien laajentumista. Mercerin ym. mukaan $(2014,295)$ "tämä tarkoittaa, että ilmastonmuutoksesta tai sellaisista alueellisen kehityksen visioista, jotka eivät liittyneet kaivosteollisuuteen, ei juurikaan suoraan keskusteltu" tässä Australiaan sijoittuneessa tapauksessa. Neoliberaali ajattelu hallitsi keskustelua siinä määrin, että se esiintyi myös ympäristöaktivistien kannanotoissa. Esimerkiksi Australiassa kaivostoimintaa vastustanut liike ei onnistunut syrjäyttämään neoliberalismia ja rakentamaan laajempia liittoumia ympäristöasioiden ympärille, koska se ei hyökännyt fossiilienergian laajempia ilmastovaikutuksia vastaan.

Monissa poststrukturalistisen diskurssiteorian tutkimuksissa metodologia kuvataan epämääräisesti eikä argumentteja selkeästi yhdistetä teoreettiseen traditioon, mutta viime aikoina tutkijat ovat alkaneet korjata tätä puutetta. Foucault'n problematisaatiokäsitystä lainaten Glynos ja Howarth $(2007,167)$ kannattavat ongelmalähtöistä lähestymistapaa käsiteltäessä sosiaalisia ja poliittisia ilmiöitä poststrukturalistisina diskursseina. Tämä lähestymistapa antaa enemmän arvoa ongelman empiiriselle kuvaukselle. Painopiste on siinä, miten eri toimijat kuvaavat ongelman, millaisia ratkaisuja he tarjoavat ja millaisia logiikkoja näiden käytäntöjen taustalla ja selittävinä tekijöinä on. Poststrukturalistinen diskurssiteoria esittää, että 
mikä tahansa asian olemus on lähtökohtaisesti epävakaa ja mahdoton ennakoida tai selittää kausaliteetilla, mikä johtaa keskeiseen ontologiseen oletukseen, joka tunnetaan sosiaalisten suhteiden radikaalina kontingenssina tai "minkä tahansa objektiviteetin kykenemättömyytenä saavuttaa täyttä identiteettiä” (Glynos \& Howarth 2007, 110). Tämän ontologisen oletuksen pohjalta Glynos ja Howarth toteavat, että ongelmalähtöinen lähestymistapa on soveltuvampi kuin aineistonkeruuta korostavat (metodilähtöiset) tai pääosin teorian todistamiseen tai kehittämiseen keskittyvät (teorialähtöiset) lähestymistavat.

Perinteisemmät lähestymistavat, kuten positivismi, kriittinen realismi ja hermeneutiikka pyrkivät ennustamaan, selittämään tai tulkitsemaan sosiaalista kanssakäymistä muodostamalla kausaalisia lakeja, kausaalisia mekanismeja tai tuottamalla itseymmärrystä. Poststrukturalistinen diskurssianalyysi sen sijaan käyttää logiikkaa selittävänä elementtinä (Glynos \& Howarth 2007; Remling 2018). Glynosin ja Howarthin mukaan "käytäntöjen logiikka muodostaa käytäntöjen säännöt tai kieliopin ja samalla ehdot, jotka mahdollistavat käytännöt ja toisaalta tekevät ne haavoittuviksi” $(2007,136)$. Tässä viitekehyksessä kolme logiikkaa auttavat hahmottamaan problematisoidun ilmiön. Ensimmäiseksi, sosiaalinen logiikka muodostaa ne säännöt ja normit, jotka määrittelevät käytännön tai käytäntöpatterin ja kysyy esimerkiksi mistä käytännöstä on kyse. Toiseksi, poliittinen logiikka pyrkii vastaamaan kysymykseen siitä miten käytäntöä haastetaan tai puolustetaan sekä miten joitakin merkityksiä korostetaan ja toisia suljetaan pois. Kolmatta logiikkaryhmää kutsutaan fantasmiseksi logiikaksi, joka selvittää miksi joitakin käytäntöjä suositaan ja toisia vältetään (Glynos \& Howarth 2007, 108). Remling $(2018,11)$ selittää tarkemmin, miten nämä kolme logiikkaa operationalisoidaan. Esimerkiksi hänen analyysissaan EU:n ilmastonmuutokseen sopeutumisen ohjelmasta, sosiaalinen logiikka näkyy erilaisina eksistentiaalisina ja arvoihin liittyvinä oletuksina asiakirjoissa. Poliittisen logiikan indikaattoreita ovat ehdotukselliset oletukset, siitä mitä pitäisi tehdä ja mitkä vaihtoehdot torjua tai poissulkea. Fantasminen logiikka joko korostaa joidenkin toimien hyötyjä, jolloin hyödynnetään autuasta ulottuvuutta, tai varoittaa niiden haitallisista seurauksista, vedoten pelottavaan ulottuvuuteen.

Tämä tutkimus korostaa lisäksi, että diskurssien tutkimuksessa on sovellettava kriittistä suhtautumista siihen, miten modernit mediajärjestelmät kannattavat hegemonisia muodostelmia, ja kyseenalaistettava niiden kykyä tuoda esiin vaihtoehtoja (Dahlberg 2011, 55).Tämän kriittisen mediapolitiikan tutkimuksen näkemyksen mukaisesti on syytä kiinnittää huomiota itse sisällön sijaan siihen, miten sen viestintä tai "antagonismin mediaalisuus" (Marchart 2011, 79) näyttää toteen sosiaalisen radikaalin kontingenssin. Näiden teoreettisten lähtökohtien pohjalta muodostuvat artikkelin tutkimuskysymykset. Mitä Jamalin pernaruttotapauksen laukaisemassa ilmastonmuutoskeskustelussa nähdään annettuna, mitä on ehdotettu tai torjuttu ja millaisilla argumenteilla? Teoreettisemmalla ja normatiivisemmalla tasolla artikkeli tarkastelee pluralistisen ilmasto-oikeudenmukaisuuden hyödyllisyyttä lähestymistapana ympäristö- ja ilmastodiskurssiin median roolin politisoinnin kautta (Dahlberg \& Phelan 2011).

\section{Valtavirran ja vaihtoehtoisen median reaktiot}

Ensimmäiset uutiset pernarutosta tulivat Jamalin Nenetsian kuvernöörin lehdistötiedotteesta 25. heinäkuuta 2016. Seuraavien viikkojen ajan aiheesta käytiin laajaa keskustelua Jamalin Nenetsian alueellisissa ja Venäjän kansallisessa mediassa, mutta vain pieni osa aineistosta viittasi ilmastonmuutokseen. Tutkimuksessa käytettiin Integrum-tietokantaa hahmottamaan, 
mitä mediassa on aiheesta raportoitu ja missä määrin uutisointi sisälsi ilmastonmuutokseen liittyviä selityksiä tai ilmasto-oikeudenmukaisuuteen viittaavia väittämiä.

Vertailtavaksi valittiin otokset kuudesta kansallisesta ja viidestä alueellisesta sanomalehdestä, joista etsittiin mainintoja "pernarutosta" aikavälillä 25. heinäkuuta ja 30 . syyskuuta 2016. Kansallinen otos $(\mathrm{N}=21)$ sisälsi 5 osumaa $(20 \%)$ ja alueellinen otos $(\mathrm{N}=94)$ toiset 5 osumaa (4\%), joissa mainittiin myös "ilmasto" tai "lämpeneminen". Valitut kansalliset sanomalehdet ovat Izvestija, Kommersant, MK, Nezavisimaja gazeta, Novaja gazeta, ja Rossijskaja gazeta. Jamalin Nenetsian alueelliset sanomalehdet ovat Vremja Jamala, Krasnyi sever, Priuralje, Rabotši Nadyma, ja Severnyi lutš. Lisäksi suoritettiin satoja verkkomedioita tai perinteisten (kansallisten tai alueellisten) sanomalehtien verkkoversioita käsittänyt Integrumhaku, jonka tarkoituksena oli varmistaa ettei uutisointi ollut merkittävän erilaista muualla Venäjän mediassa. Alustava tutkimus osoitti ja myöhempi tarkastelu vahvisti, että kansallisen tason viestimillä oli yksi päälähde, jossa pernarutto yhdistettiin suoraan ilmastonmuutokseen: Venäjän Greenpeace. ${ }^{1}$ Ympäristöjärjestö julkisti oman lausuntonsa verkkosivuillaan (Greenpeace 2016). Novaja gazeta (NG) haastatteli useaa Greenpeacen aktivistia tutkivassa artikkelissaan, joka osoittaa miten vähäistä huomiota kansainväliset ympäristöjärjestöt saavat Venäjällä. Tutkimukseen valitun otoksen joukossa NG on kriittisin Venäjän nykyhallintoa kohtaan, ja sillä on myös todennäköisesti pienin lukijakunta.

Lisähaun perusteella muutkin viestimet viittasivat Greenpeacen alkuperäiseen lehdistötiedotteeseen, mutta NG:n uutisointi oli kaikkein kattavinta. Tärkeä kriittinen hetki Greenpeacen viestinnässä on, että ilmastonmuutoksen ja pernaruton välisen yhteyden lisäksi alkuperäinen tiedote sisältää kappaleen mittaisen varoituksen, jonka mukaan uudet öljy- ja kaasuhankkeet Jamalilla saattavat aiheuttaa lisää pernaruttoa tulevaisuudessa, kun ikiroudan sulaminen avaa uusia, mahdollisesti infektoituneita alueita kaivannalle. Vaikka Greenpeace poisti tämän kappaleen uutissivultaan muutamaa päivää myöhemmin, useat kansallisen tason viestimet sisällyttivät sen uutisointiinsa aiheesta. Tämä uutinen toistaa Greenpeacen sinnikästä kampanjaa arktista öljynporausta vastaan. Sen ilmestyminen verkkoon on voinut olla myös yritys työntää kiilaa suuryritysten ja alkuperäiskansojen välille ja kyseenalaistaa vallitsevaa paternalistista suhdetta. Se kuitenkin vesitti samalla mahdollisuuden käyttää pernaruttotapausta potentiaalisesti voimakkaastikin haastamaan Venäjän ympäristönsuojeludiskurssia, jota Tokunaga (2018) kuvaa talous- ja turvallisuuslähtöiseksi, ja käynnistää keskustelua ilmasto-oikeudenmukaisuudesta median kautta. Greenpeacen viestin kaksinaisuus asetti sen haavoittuvaksi diskursiiviselle torjunnalle.

Elokuun 2016 aikana Greenpeacen aktivistit pyrkivät matkustamaan karanteenialueelle tutkiakseen tapausta. Koska Jamalin rosoinen maaperä tekee muun kuin helikopterilla liikkumisen mahdottomaksi, aktivistit olivat liikennöintiä hallitsevien paikallisviranomaisten varassa. Kansallisessa mediassa uutisoitiin, että paikallislennon peruuntuessa aktivistit uskoivat viranomaisten tarkoituksellisesti estävän heidän työtään. He pitivät tilannetta epäilyttävänä ja väittivät, että kyseessä oli tarkoituksellinen yritys peitellä todellista infektiotilannetta. Greenpeace ei olisi pystynyt levittämään tätä viestiään laajemmalle yleisölle pelkästään oman verkkosivunsa ja sosiaalisen median kautta. Suuri osa sen saamasta julkisuudesta tapahtumien aikana tuli myös tämän tutkimuksen aineistoon sisältyvästä perinteisestä mediasta, jonka suosio oli kuitenkin rajattua verrattuna valtavirran päivälehtiin ja televisioon. Tutkivasta journalismistaan tunnettu Novaja Gazeta oli raportoinnissaan vahvasti Greenpeacen lähteiden varassa. 
Huolimatta Greenpeacen kansallisista ja paikallisista toimista Jamalilla, yksikään Jamalin Nenetsian media ei maininnut järjestöä. Tähän sääntöön oli ainoastaan yksi poikkeus, kun karanteeni saman vuoden syyskuussa lopetettiin ja alueellisen TV-kanavan toimittaja kysyi Jamalin Nenetsian kuvernööriltä Greenpeacen öljy-yhtiöitä koskevista väitteistä. Niitä ei ollut koskaan käsitelty alueellisessa mediassa, vaan ne sisältyivät ainoastaan Greenpeacen tiedotteesta poistettuun kappaleeseen, joten väitteet saattoivat päätyä paikallisen median tietoisuuteen vain kansallisen tason viestimistä ja niiden jakamisesta sosiaalisessa mediassa. Vastauksessaan kuvernööri kuitenkin sivuutti aktivistien pääargumentin ilmastonmuutoksesta ja energiajäteistä sen aiheuttajina.

Yleisen uutismedian lisäksi vuoden 2016 pernaruttoesiintymä kirvoitti luonnollisesti lukuisia asiantuntijakommentteja konferensseissa ja erikoistuneilla media-alustoilla. Esimerkiksi Farmatsevtitšeski vestnik (farmasia-alan lehti) haastatteli useita tieteilijöitä, jotka eivät olleet klimatologeja, pyrkimyksenään selvittää tapauksen syitä ja ratkaisuja (Kalinovskaja 2016). Artikkelissa spekuloitiin, että ihmiskunta ei pysty pysäyttämään ilmaston lämpenemistä, koska kasvihuonekaasupäästöjä rajoittamaan solmittu Kioton sopimus ei toiminut kunnolla. Artikkelin mukaan ihmisten tulisi kasvihuoneilmiön puntaroimisen sijaan keskittyä monitoroimaan ympäristöä, kartoittamaan hautapaikkoja ja selvittämään, missä ikiroudan sulamista tulee tapahtumaan. Yksi haastatelluista oli epidemiologi, joka moitti vähäistä tutkimusrahoitusta. Hän muisteli, että valtion viranomaiset olivat järjestäneet ilmastoaiheisen konferenssin ja kehittäneet erityisen hallituksen alaisen ohjelman reaktiona vuoden 2010 kuivuusaaltoon Keski-Venäjällä, mutta eivät olleet varanneet rahaa ohjelman toteuttamiseen. Artikkeli varoitti, että "infektio-Armageddon" olisi vältettävissä ainoastaan riittävän monitoroinnin ja varhaisen diagnosoinnin avulla, ja että tätä varten hallituksen olisi luotava "porkkanoita" sijoittajien houkuttelemiseksi. Kaikkiaan tässä asiantuntijoiden näkemyksiä kartoittaneessa, erityisalaan suuntautuneessa uutislähteessä ilmastonmuutos esitettiin yksinomaan sopeutumiseen ja tehokkaaseen hallintoon liittyvänä ongelmana, ei hillittävissä olevana asiana.

\section{IImasto-oikeudenmukaisuusviestinnän diskursiivinen logiikka}

Suurin osa ilmasto-oikeudenmukaisuutta käsittelevästä kirjallisuudesta käyttää viitekehyksenä erilaisia yhteiskunnallisia näkökulmia korostaen epäoikeudenmukaista ilmastonmuutoksen hillintätaakkaa tai ilmastoon liittyvien riskien jakautumista sosiaalisten ryhmien, valtioiden tai yhteisöjen välillä nyt ja tulevaisuudessa. Nousussa oleva pluralistinen lähestymistapa laventaa oikeudenmukaisuuden subjektien kenttää ottamalla huomioon myös epäinhimillisen luonnon (Agyeman et al. 2016, 334-36; Schlosberg 2009). Tässä lähestymistavassa problematisoidaan eriarvoisuus ihmisten ja muiden eliöiden välillä eli ekologinen oikeudenmukaisuus, joka usein jää huomioimatta pelkästään ihmisten välistä eriarvoisuutta eli ympäristöoikeudenmukaisuutta tarkastelevilta yhteiskuntatieteilijöiltä ja yhteiskunnallisilta liikkeiltä. Schlosbergin mukaan pluralistinen lähestymistapa ilmasto-oikeudenmukaisuuteen vahvistaa ilmastoliikkeiden argumentaatiota ja mobilisaatiokykyä.

Luonnonympäristön huomioiminen ilmasto-oikeudenmukaisuudessa on erityisen aiheellista nenetsipaimentolaisten näkökulmasta katsottuna, sillä heidän sosiaalinen identiteettinsä on erottamattomissa heidän ekologisesta identiteetistään (Forbes 2013; Forbes \& Stammler 2009). Tämä näkyy esimerkiksi tarkasteltaessa sitä monimutkaista järjestelmää, jonka avulla tehdään päivittäisiä päätöksiä siitä minne liikutaan, miksi ja miten nopeasti, riippuen muun muassa lämpötilasta, tuulen suunnasta, hyönteisten määrästä, lumen syvyydestä ja laadusta, 
poroille tarjolla olevasta ravinnosta ja eläinten kunnosta. Porolauman suuruus, kompositio ja terveydentila ovat myös välttämättömiä näkökohtia harkittaessa, voiko vaellus jatkua. Viime vuosikymmeninä Jamalin nenetsit ovat säilyttäneet perinteisen kulttuurinsa suhteellisen muuttumattomana - päinvastoin kuin useimmat muut Venäjän alkuperäiskansat. Etnografit linkittävät tämän kulttuurisen resilienssin suoraan paimentolaisten elämäntapaan (Golovnev \& Osherenko 1999). Koska nenetseillä ei ole vakituisia asumuksia tai maita ja heidän pääsynsä ammatilliseen koulutukseen on heikkoa, nenetseillä ei ole ollut muuta vaihtoehtoa kuin jatkaa paimentolaisuutta. Jatkuvan vaeltamisen ansiosta he ovat pystyneet välttämään paikallisia, yllättäviä ympäristöriskejä ja säilyttämään porokarjansa. Yksi syy jatkuvalle vaellukselle on porojen luontainen taipumus liikkua lämpimämpänä aikana pohjoiseen pakoon hyönteislaumoja ja lähemmäs Jäämeren rauhoittavia tuulia.

Teollisuuden nopea kehitys, joka alkoi Jamalin niemimaalla 1980-luvulla ja kiihtyi entisestään 2000-luvulla, on häirinnyt nenetsien perinteistä elämäntapaa (Degteva \& Nellemann 2013). Öljynporauspaikat, kaasuputket ja maantiet risteilevät paimentolaisten vuosittaisten vaellusreittien halki. Sillanrakennus tukkii väliaikaisesti jokia, aiheuttaa tulvia laidunmaille ja pakottaa kalakannat siirtymään. Terävät metalli- ja lasipalat saattavat myös vahingoittaa poroja kuolettavasti. Toisaalta öljynporauskohteiden lähelle majoittuminen voi olla myös hyödyllistä nenetseille. He myyvät porotuotteita teollisuuden työntekijöille tai vaihtavat niitä muihin ruokiin, lääkkeisiin sekä raaka-aineisiin ja saavat lisäksi apua öljy-yhtiöiden järjestämistä kuljetuspalveluista.

Vaikka Venäjän alueellisessa ympäristöoikeudenmukaisuutta käsittelevässä diskurssissa syytetään pääosin öljy- ja kaasuteollisuutta ympäristöuhkien pahenemisesta, siihen sisältyy usein myös ekologiseen oikeudenmukaisuuteen liittyviä kysymyksiä. Niitä kuitenkin nostavat enimmäkseen kansainväliset järjestöt, eivät niinkään paikalliset asukkaat itse (Agyeman \& Ogneva-Himmelberger 2009, 277). Kuten Tokunaga $(2018,133)$ toteaa, Venäjän sisäisessä diskurssissa arktisen luonnon suojelu yhdistyy yleensä energiantuotannon laajentumiseen ja Jäämeren väylään liittyviin taloudellisiin kysymyksiin. Tilanteeseen vaikuttavat olennaisesti myös paikallisten yhteisöjen ja kaivosyhtiöiden väliset suhteet, joita kuvataan neo-paternalistisiksi. Neuvostoaikaisen hyvinvointijärjestelmän romahdettua mikään mekanismi ei velvoita suuryhtiöitä tukemaan sosiaalista elämää ja infrastruktuuria etäisillä alueilla (Henry et al. 2016). Porojen määrä Pohjois-Venäjällä on vähentynyt jatkuvasti 1960-luvulta alkaen yhtä poikkeusta lukuun ottamatta: Jamalin nenetsien karjan määrä kasvoi jopa 1990-luvun alun kriisin aikana Neuvostoliiton hajottua. Kuten Klokov (2013) on todennut, nenetsien menestykseen johtivat vaeltavan elämäntavan suuri rooli sekä öljy- ja kaasuteollisuudesta maaseudun talouteen virrannut raha.

Hoitaessaan pernaruttoepisodin jälkiseuraamuksia Jamalin Nenetsian viranomaiset päätyivät lopulta hyväksymään käsityksen, jonka mukaan lämmin sää vaikutti osasyynä tapahtumiin, sillä se uuvutti porot ja teki niistä haavoittuvampia. Alueelliset viranomaiset esittivät useita eksistentiaalisia ja arvovärittyneitä väittämiä, joissa normalisoitiin nenetsien perinteinen elämäntapa resilienttinä hätätilanteille ("tundralla taudin infektoimilla alueilla elävä väestö tietää, mitä tehdä ja toimii sen mukaisesti”) (Vremja Jamala 2016a). Sama diskursiivinen sosiaalinen logiikka myös otti annettuna arktisen alueen yleisesti vaativan ilmaston ja karut elinolosuhteet, joiden muodostamassa viitekehyksessä ei ole sijaa valittaa ilmastonmuutoksesta. Tämän logiikan perusteella Greenpeacen fossiilienergiayhtiöitä kritisoiva kampanja ilmasto-oikeudenmukaisuuden puolesta ei resonoi paikallisen väestön keskuudessa, sillä heille vaikeat sääolosuhteet ovat normi ja öljy- ja kaasuyhtiöt tuovat vakautta. 
Diskurssiteoreettinen poliittinen logiikka tapauksen käsittelyyn puolestaan pitää sisällään ekologisen oikeudenmukaisuuden elementtejä. Alueelliset viranomaiset ilmoittivat ympäristötieteilijöiden tukemina, että porojen liian suuri populaatio oli ratkaiseva tekijä, joka pakotti paimenet kielletyille alueille ja saivat aikaan tautiesiintymän (Kolosov 2016). Asiantuntijoiden mukaan Jamalin ekosysteemi pystyy normaalisti ylläpitämään poropopulaation, joka on kolmanneksen nykyisestä 300000 yksilöstä. Lopputulemana syntyi päätös, että hallitus pyrkisi löytämään keinoja siirtää joitakin nenetsiperheitä etelän metsäalueille tai kannustaa heitä luopumaan vaelluselämäntavastaan ja esimerkiksi asettumaan kaupunkeihin kalastajiksi tai käsityöläisiksi. Tämä logiikka perustuu täysin tundraan kohdistuvan ekologisen paineen vähentämiseen ja jättää huomiotta teollisten kehitysprojektien rajoittamisen, vaikka juuri teollisuus on heikentänyt Jamalin tundran kykyä kestää paimentolaisyhteisöjen määrän kasvua. Mikäli Greenpeace olisi pyrkinyt haastamaan tätä logiikkaa pluralistisemmalla lähestymistavalla korostamalla myös suuryhtiöiden paikallista eikä vain globaalia ekologista vastuuta, se olisi saattanut onnistua paremmin mobilisoimaan vaihtoehtoisia diskursseja.

Toisin kuin paikallisella Jamalin Nenetsian uutismedialla, kansallinen media oli autonomisempi, mikä mahdollisti alueellisten seikkojen kyseenalaistamisen ja ilmastonmuutoksen tuomisen keskusteluun. Kansallisesta mediasta tulikin diskurssissa fantasmisen logiikan välittäjä. Jo mainittu Novaja gazeta haastatteli Greenpeacen aktivisteja ja nenetsejä, jotka väittivät tuntevansa tapauksen yksityiskohdat. Koska pääsy karanteenialueelle oli estetty, useiden lausuntojen todenmukaisuuden tarkistaminen oli vaikeaa. Siksi syntyi salaliittoteorioita, joista erään mukaan hallitus ripotteli salaa pernaruttoitiöitä tundralle pelottaakseen alkuperäiskansan pois mailtaan ja raivatakseen tilaa öljy- ja kaasuyhtiöille. Nämä teoriat muodostavat vaihtoehtoisessa diskurssissa fantasmisen logiikan pelottavan ulottuvuuden.

Vallalla ollut diskurssi keskittyi enemmän autuaaseen ulottuvuuteen palauttamalla dislokaation kohteeksi joutuneet tilat ennalleen. Siinä korostettin yhtenevän virallisen tiedon ja hallituksen kontrollin hyötyjä kriisitilanteessa. Kun kuvernööri vastasi Greenpeacen syytöksiin, kyseessä oli myös vastaus lukuisiin kantoihin ja syytöksiin, joita esitettiin (ja mahdollistettiin) kansallisessa mediassa. Toisessa tapauksessa kuvernööri ylisti Jamalin kuntien ja liikeelämän solidaarisuutta, kun nämä tukivat taloudellisesti pernaruton puhkeamisesta kärsineitä paimentolaisia ja auttoivat heitä dekontaminaatiossa sekä tavalliseen elämään palaamisessa. "[Pernaruttotapaus] yhdistää meitä alkuperäiskansaan. Nyt, paljon enemmän kuin koskaan aiemmin, he ovat nähneet ja ymmärtäneet valtion roolin elämässään. Tilanne on osoittanut, että olemme samassa veneessä ja palvelemme samaa tarkoitusta” (Vremja Jamala 2016b). Samankaltaisella tavalla autuas oikeutus tälle fantasmiselle logiikalle korosti, että virallisen tiedon rajallisuus on parempaa, luotettavampaa ja sosiaalisesti vastuullisempaa, sillä se pyrkii säilyttämään järjestyksen ja estämään paniikin sen sijaan, että levittäisi salaliittoteorioita ja huhuja, joiden joskus nähtiin olevan peräisin ulkomailta. Esimerkiksi vallitsevan diskurssin pelottava ulottuvuus stigmatisoi Greenpeacea ulkomaalaisena järjestönä, joka säännöllisesti hyökkää Venäjän fossiilienergiateollisuutta vastaan pyrkien kyseenalaistamaan sen legitimiteetin ja näin häiritsemään Venäjän taloudellisia intressejä valheellisilla ympäristönsuojeluun liittyvillä motiiveilla.

\section{Kaksinkertaisen dislokaation epäonnistuminen}

Kuten analyysi osoittaa, pernaruttoa ilmastonmuutoksen yhteydessä käsitelleiden mediajulkaisujen vähäinen määrä korostaa, miten olematonta kiinnostus ilmastoon liittyviin 
selityksiin Venäjällä vielä on, vaikka niistä voisi tulla ratkaisevia alueellisten ympäristö- ja ilmasto- oikeudenmukaisuusväittämien kannalta. Tässä artikkelissa analysoitu aineisto myös osoittaa, miten vähäistä ekologista oikeudenmukaisuutta vaativan liikkeen - tässä tapauksessa Venäjän Greenpeacen - vaikutus Venäjän alueelliseen ja kansalliseen mediaan on. Vuonna 2012 Greenpeace aloitti "Pelastakaa Arktinen" kampanjan. Sen osana, Jamalin vuoden 2016 tapahtumien aikana, joukko Greenpeacen jäseniä matkusti alueelle ja teki lyhytelokuvia alkuperäiskansa nenetseistä, pernaruton puhkeamisesta ja ilmastonmuutoksesta. Sen paremmin nämä elokuvat kuin mitkään muutkaan Greenpeacen pernaruttotapausten aikana järjestämät julkiset kampanjat eivät nousseet valtavirran keskusteluun.

Kansallisella tai alueellisella tasolla vallitseva mediadiskurssi Venäjällä ei näe ristiriitoja ympäristönsuojelun ja talouskehityksen välillä arktisella alueella. Siinä otetaan harvoin huomioon ilmastonmuutosta. Poststrukturalistisen diskurssiteorian viitekehystä hyödyntäen tässä tutkimuksessa korostuu Venäjän Greenpeacen pyrkimys käyttää pernaruton puhkeamista häiritsemään (dislocate) ja haastamaan tätä lähtökohtaa osana omaa ilmasto-oikeudenmukaisuuskampanjaansa. Greenpeacen yritys tuoda ilmasto-oikeudenmukaisuus kansallisen ja alueellisen tason mediaan päätyi pelamaan kaksilla korteilla. Toisaalta se onnistui kiinnittämään rajallista mediahuomiota kansallisella tasolla, jolla on enemmän valtiosta riippumattomana toimijoita ja siten mahdollisuuksia esittää kriittisiä kysymyksiä etenkin alueellisissa aiheissa. Kenties merkittävimpänä seurauksena Jamalin Nenetsian kuvernöörin oli annettava virallinen vastaus alueellisella televisiokanavalla. Vastauksessa kuitenkin siirrettiin huomio ilmastonmuutoksesta ja fossiilienergiayhtiöiden ekologisesta vastuusta Venäjän strategisten intressien suojelemiseen arktisella alueella ja Greenpeacen "ulkomaisiin" yrityksiin häiritä niitä. Greenpeacen esillä pitämä ilmasto-oikeudenmukaisuusteema noudatti perinteisiä oikeudenmukaisuusväittämiä ja perustui muun muassa resurssien jakoon ja sosiaalisten toimijoiden välisiin, taloudellisiin suhteisiin rajattuihin kyvykkyyksiin. Mikäli se olisi ollut pluralistisempi ja seurannut esimerkiksi sosio-ekologista oikeusfilosofiaa (Schlosberg 2009), potentiaalisten diskursiivisten yhteenliittymien ja suuren yleisön hyväksynnän mahdollisuus olisi ollut suurempi.

Toisaalta taas Greenpeacen toimien käsittely mediassa sekä järjestön pääsyn estäminen hätätila-alueelle paljastavat tahattomasti kokonaan toisenlaisen väittämän, jota ilmastooikeudenmukaisuusliike ei vielä ole sisällyttänyt ohjelmiinsa Venäjällä. Kyseessä on vaatimus pääsystä luotettavan ja ajankohtaisen ekologisen tiedonvälityksen äärelle. Hätätilassa tiedon puute on haitallista julkiselle viestinnälle, sillä se saa aikaan salaliittoteorioita, joita kontrolloitujen uutistoimistojen on helppo osoittaa vääriksi (mihin tämän artikkelin empiirinen tutkimus on kohdistunut) mutta joita on vaikeampi käsitellä verkkofoorumeilla ja sosiaalisen median sivustoilla. Mahdollisen jatkotutkimuksen aiheena onkin syytä huomata, että tämän tutkimuksen kohteena olleena aikana ne Greenpeacen argumentit, joita ei esiintynyt alueellisissa sanomalehdissä, levisivät kuitenkin laajalti Jamalin sosiaalisen median ryhmissä. Tämä lienee syynä siihen, että kuvernööriä lopulta pyydettiin kommentoimaan asiaa.

Löydökset tuovat esiin poststrukturalistisen diskurssiteorian rajotuksia ja nyansseja. Dislokaatiota luovat elementit Jamalin pernaruttotapauksessa syntyivät ainoastaan marginaalisten vaihtoehtoisten toimijoiden (eli Greenpeacen) aikaansaannoksena. Heidän poliittinen logiikkansa, joka perustui fossiilienergiayhtiöiden syyttämiseen ympäristötuhoista, vaikutti heikolta eikä välttämättä todenmukaiselta. Vallitseva diskursiivinen logiikka puolestaa yhdisti Jamalin väestön yleisen hyvinvoinnin alueen taloudelliseen kehitykseen eikä niinkään ekologisen oikeudenmukaisuuden vaatimuksiin. Ennennäkemättömät toimenpiteet 
pernaruttotilanteen hallitsemiseksi ja uhan ekologinen mittakaava olivat luonteeltaan dislokationaarisia. Ne johtivat pakollisten rokotusten palauttamiseen ja herättivät keskustelua tieteellisillä ja asiantuntijaforumeilla. Poststrukturalistien diskurssiteorian mukaan kuitenkin vaihtoehtoisten liikkeiden synnyn kannalta välttämätön on myös toinen (sosioekonominen) dislokaatio, jota tässä tapauksessa joko ei tapahtunut tai se ei seurannut sopivaa diskursiivista logiikkaa. Tämä antaa aihetta dislokaation käsitteen määrittävien tekijöiden teoreettiselle kehittämiselle myös jatkossa.

\section{Viitteet}

1 Lisäksi Venäjän Federaation hydrometeorologian ja ympäristöseurannan palvelu Rošydromet esitti vastaavia väittämiä, mutta sen lehdistötilaisuudesta ei uutisoitu merkittävästi missään viestimissä.

\section{Lähteet}

\section{Aineisto}

Avakov, Artur (2016) Pervaja za 75 let vspiška sibirskoi jazvi istrebljaiet Jamal, $M K, 1.08 .2016$, https:// www.mk.ru/social/health/2016/08/01/pervaya-za-75-let-vspyshka-sibirskoy-yazvy-istreblyaetyamal.html (Tarkistettu 17.5.2020).

Borisov, Timofei (2016) Sever v ogne, Rossijskaja gazeta, 31.07.2016, https://rg.ru/2016/07/31/ reg-urfo/mchs-usilil-gruppirovku-na-iamale-iz-za-lesnyh-pozharov.html (Tarkistettu 17.5.2020).

Britskaja, Tatjana (2016) Nav skazali, tšto eto inostrantsi s samoljota zarazu rassipali, Novaya gazeta, 10.08.2016, https://www.novayagazeta.ru/articles/2016/08/10/69494-nam-skazali-chto-etoinostrantsy-s-samoleta-zarazu-rassypali (Tarkistettu 17.5.2020).

Gantšerko, Vladimir (2016) Jamalski metod borbi s "sibirkoi" priznali unikalnim, Krasnyi sever, 16.11.2016, https://ks-yanao.ru/obshchestvo/yamalskiy-metod-borby-s-sibirkoy-priznali-unikalnym.html (Tarkistettu 17.5.2020).

Greenpeace (2016) V rasprostranenii sibirskoi jazvi na Jamale vinovno izmenenie klimata, Greenpeace Russia, 3.08.2016, https://web.archive.org/web/20190902031641/http://www.greenpeace.org/ russia/ru/news/2016/03-08-2016_sibirskaya_yazva_climat/ (Tarkistettu 17.5.2020).

Jegorova, Alina (2016) Tjažjoloe leto olenego kraja, Rossijskaja gazeta, 10.08.2016, https:// rg.ru/2016/08/09/karantinu-na-iamale-otvedeno-eshche-dve-nedeli.html (Tarkistettu 17.5.2020).

Kalinovskaja, Jelena (2016) Infektsionni Armageddon, Farmatsevtitseskii vestnik, 16.08.2016, https:// pharmvestnik.ru/articles/infektsionnyj-armageddon.html_(Tarkistettu 17.5.2020).

Kolosov, Danil (2016) Potšemu "ožila" sibirskaja jazva: versii i posledstvija, Krasnyi sever, 8.09.2016, https://www.ks-yanao.ru/obshchestvo/pochemu-ozhila-sibirskaya-yazva-versii-i-posledstviya.html (Tarkistettu 17.5.2020). 
Kommersant (2016) Grinpis vinit vo vspiške sibirskoi jazvi na Jamale globalnoe poteplenie, Kommersant, 5.08.2016, https://www.kommersant.ru/doc/3055188 (Tarkistettu 17.5.2020).

Melnikova, Žanna (2016) Tundra protiv kommertsii, Rossijskaia Gazeta in Ural Federal District, 9.09.2016, https://rg.ru/2016/09/08/reg-urfo/uchenye-predupredili-ob-opasnosti-bolshogo-chislaolenej-dlia-iamala.html (Tarkistettu 17.5.2020).

Rybjakova, Natalia (2016) Epidemii na Jamale - net. Karantin vvedjon lokalno, Krasnyi sever, 3.08.2016, https://ks-yanao.ru/vlast/epidemii-na-yamale-net-karantin-vvedyen-lokalno.html (Tarkistettu 17.5.2020).

Vremja Jamala (2016a) Hronika sanitarnogo karantina na Jamale, Vremja Jamala, 5.08. 2016, https:// www.mo-yamal.ru/load/31748516 (Tarkistettu 18.5.2020).

Vremja Jamala (2016b) Mi splotilis. I pobedim, Vremja Jamala, 12.08.2016, https://www.mo-yamal. ru/load/32748616 (Tarkistettu 18.5.2020).

\section{Kirjallisuus}

Agyeman, J., Schlosberg, D., Craven, L., \& Matthews, C. (2016). Trends and directions in environmental justice: from inequity to everyday life, community, and just sustainabilities. Annual Review of Environment and Resources, 41:1, 321-340.

Agyeman, Julian, and Yelena Ogneva-Himmelberger, toim. (2009). Environmental justice and sustainability in the former Soviet Union. Cambridge, MA: MIT Press.

Boykoff, M. T. (2008). The cultural politics of climate change discourse in UK tabloids. Political geography, 27:5, 549-569.

Dahlberg, Lincoln and Sean Phelan (2011). Discourse Theory and Critical Media Politics. Basingstoke: Palgrave Macmillan.

Dahlberg, Lincoln. (2011). Discourse Theory as Critical Media Politics? Five Questions. In Discourse Theory and Critical Media Politics, ed. Lincoln Dahlberg and Sean Phelan, 41-63. Basingstoke: Palgrave Macmillan.

Degteva, Anna, and Christian Nellemann (2013). Nenets migration in the landscape: impacts of industrial development in Yamal peninsula, Russia, Pastoralism: Research, Policy and Practice $3,15,1-21$.

Forbes, B. (2013). Cultural resilience of social-ecological systems in the Nenets and Yamal-Nenets Autonomous Okrugs, Russia: a focus on reindeer nomads of the tundra. Ecology and Society, 18:4, 36.

Forbes, B. C., \& Stammler, F. (2009). Arctic climate change discourse: the contrasting politics of research agendas in the West and Russia. Polar Research, 28:1, 28-42.

Glynos, J., \& Howarth, D. (2007). Logics of critical explanation in social and political theory. Abingdon: Routledge.

Golovnev A. V., and G. Osherenko (1999). Siberian survival: the Nenets and their story. Ithaca, NY: Cornell University Press, USA.

Golovnev, A. V. (2017). Challenges to Arctic Nomadism: Yamal Nenets Facing Climate Change Era Calamities. Arctic Anthropology, 54:2, 40-51.

Gritsenko, Daria \& Tynkkynen, Veli-Pekka (2016). Arktinen Venäjän poliittisessa viestinnässä. Idäntutkimus 4, 3-18.

Henry, L. A., Nysten-Haarala, S., Tulaeva, S., \& Tysiachniouk, M. (2016). Corporate social responsibility and the oil industry in the Russian Arctic: Global norms and neo-paternalism. Europe-Asia Studies, 68:8, 1340-1368.

Klokov K. B. (2013). Changes in reindeer population numbers in Russia: an effect of the political context or of climate? Rangifer, 32:1, 19-33. https://doi.org/10.7557/2.32.1.223

Laclau, E. (1990). New reflections on the revolution of our time. London: Verso.

Laishev K.A., Zabrodin V.A. (2012). Problemy veterinarnogo blagopoluchiia po infektsionnim bolezniam v Severnom olenevodstve. Farm Animals, 1, 36-40.

Marchart, Oliver (2011). From Media to Mediality: Mediatic (Counter-)Apparatuses and the Concept of the Political in Communication Studies. In Discourse Theory and Critical Media Politics, ed. Lincoln Dahlberg and Sean Phelan, 64-81. Basingstoke: Palgrave Macmillan.

Mercer, A., de Rijke, K., \& Dressler, W. (2014). Silences in the boom: coal seam gas, neoliberalizing discourse, and the future of regional Australia. Journal of Political Ecology, 21:1, 279-302. 
Poberezhskaya, M. (2015). Media coverage of climate change in Russia: Governmental bias and climate silence. Public Understanding of Science. 24:1, 96-111.

Remling, E. (2018). Logics, assumptions and genre chains: a framework for poststructuralist policy analysis. Critical Discourse Studies, 15:1, 1-18.

Revich, B. A., and Podolnaya, M. A. (2011) Thawing of permafrost may disturb historic cattle burial grounds in East Siberia. Global Health Action, 4:1, 8482, 1-6.

Schlosberg, D. (2009). Defining Environmental Justice: Theories, Movements, and Nature. Oxford: Oxford University Press.

Stavrakakis, Y., (2000). On the emergence of Green ideology: The Dislocation Factor in Green Politics. In Discourse theory and political analysis. Identities, hegemonies and social change, Eds. D. Howarth, A. Norval, and Y. Stavrakakis, Manchester: Manchester University Press, 100-118.

Timofeev V, Bahtejeva I, Mironova R, Titareva G, Lev I, Christiany D, et al. (2019). Insights from Bacillus anthracis strains isolated from permafrost in the tundra zone of Russia. PLoS ONE 14.5, e0209140. https://doi.org/10.1371/journal.pone.0209140

Tokunaga, M. (2018). Russian Arctic development and environmental discourse. In Russia's Far North. Contested Energy Frontier, Eds. V-P. Tynkkynen, S. Tabata, D. Gritsenko and M. Goto Abington: Routledge, 129-146.

Tynkkynen, Veli-Pekka (2019). The Energy of Russia: Hydrocarbon Culture and Climate Change. Cheltenham: Edward Elgar Publishing.

Walsh, M.G., de Smalen, A.W. and Mor, S.M. (2018). Climatic influence on anthrax suitability in warming northern latitudes. Scientific Reports 8, 9269.

Wilson Rowe, E. (2009). Who is to blame? Agency, causality, responsibility and the role of experts in Russian framings of global climate change. Europe-Asia Studies, 61:4, 593-619.

Yagodin, D. (2017). Climate Change Communication in Russia. In Oxford Research Encyclopedia of Climate Science. DOI: 10.1093/acrefore/9780190228620.013.465. 